\title{
PERHITUNGAN DAYA DUKUNG LINGKUNGAN BERDASARKAN KETERSEDIAAN AIR DAN PRODUKTIVITAS LAHAN DI KECAMATAN TUJUH BELAS KABUPATEN BENGKAYANG
}

\author{
Anggun Rea Pramesty ${ }^{1}$ Azwa Nirmala ${ }^{2}$, Asripin Aspan ${ }^{3}$ \\ ${ }^{1}$ Program Studi Teknik Lingkungan, Fakultas Teknik, Universitas Tanjungpura, Pontianak \\ ${ }^{2}$ Program Studi Teknik Sipil Fakultas Teknik, Universitas Tanjungpura Pontianak \\ ${ }^{3}$ Program Studi Ilmu Tanah Fakultas Pertanian, Universitas Tanjungpura Pontianak \\ Email : anggunrea@gmail.com
}

\begin{abstract}
ABSTRAK
Menurut UU No. 32 Tahun 2009 daya dukung lingkungan hidup adalah kemampuan lingkungan hidup untuk mendukung perikehidupan manusia, makhluk hidup lain, dan keseimbangan antar keduanya.. Lokasi penelitian terletak pada Kecamatan Tujuh Belas, Kabupaten Bengkayang, yang berdasarkan data BPS Kabupaten Bengkayang tahun 2013 dengan kepadatan penduduk yaitu sebesar 11.538 jiwa. Kecamatan Tujuh Belas merupakan daerah pemukiman agraris yang terus berkembang, namun taraf hidup penduduk di Kecamatan Tujuh Belas masih relatif rendah. Rendahnya taraf hidup penduduk ditinjau dari aspek daya dukung air dan daya dukung lahannya. Tujuan penelitian ini menentukan nilai surplus/defisit dengan membandingkan ketersediaan dan kebutuhan air, menentukan nilai surplus/defisit dengan membandingkan ketersediaan dan kebutuhan lahan, serta memberikan rekomendasi untuk ketersediaan dan kebutuhan air serta ketersediaan dan kebutuhan lahan, Meningkatkan taraf hidup penduduk Kecamatan Tujuh Belas yang ditinjau dari daya dukung air dan daya dukung lahan.

Metodologi yang digunakan untuk menentukan daya dukung air dan daya dukung lahan mengacu pada Permen LH No. 17 Tahun 2009. Berdasarkan hasil penelitian yang mengacu pada Permen Lh No 17 tahun 2009, untuk ketersediaan air di Kecamatan Tujuh Belas pada tahun *(2014 - 2023) diperkirakan sama dan tidak bertambah yaitu sebesar \#77.451.118 $\mathrm{m}^{3} /$ tahun dikarenakan dalam penggunaan lahan untuk tahun *(2014 2023) tidak diketahui, sedangkan untuk kebutuhan air pada tahun 2013 sebesar $18.460 .800 \mathrm{~m}^{3} /$ tahun dan pada tahun 2023 mengalami peningkatan yaitu sebesar $23.775 .300 \mathrm{~m}^{3} /$ tahun. Hasil yang diperoleh dari penelitian ini adalah daya dukung air di Kecamatan Tujuh Belas surplus hal ini menunjukkan ketersediaan air yang sekarang dan prediksi untuk 10 tahun kedepan mencukupi kebutuhan air baik dari segi kebutuhan domestik maupun kebutuhan pangan dan lainnya. Sebaiknya kondisi yang sekarang dipertahankan sesuai dengan fungsi lahannya. Ketersediaan lahan di Kecamatan Tujuh Belas adalah 8641,489 ha, sedangkan kebutuhan lahannya adalah sebesar 4807,50 ha. Untuk kebijakan pengembangan di sektor pertanian sebagai sektor unggulan di Kecamatan Tujuh Belas, maka dapat diarahkan untuk memenuhi kebutuhan pasar yang lebih luas ke luar wilayah dengan mengembangkan aksesibilitas pemasaran ke luar wilayah. Rendahnya taraf hidup penduduk Kecamatan Tujuh Belas tidak berkaitan dengan daya dukung air dan daya dukung lahan, karena berdasarkan perhitungan ketersediaan air dan kebutuhan air serta ketersediaan lahan dan kebutuhan lahan menunjukkan bahwa daya dukung lingkungannya mencukupi untuk kebutuhan manusia baik domestik maupun domestik. Kemungkinan yang menyebabkan taraf hidup rendah disebabkan oleh hal lain seperti : pendidikan yang minim, fasilitas kesehatan, dan infrastuktur yang tidak memadai penduduk untuk membawa hasil panen ke kota.
\end{abstract}

Kata Kunci: Kecamatan Tujuh Belas, Daya Dukung Lingkungan Defisit,Surplus

\section{ABSTRACT}

According to Law No. 32, 2009 the carrying capacity of the environment is the environment 's ability to support humans, other living creatures, and the balance between the two. Location of the study lies in the District of Seventeen, Bengkayang, which is based on BPS data Bengkayang in 2013 with a population density that is equal to 11538 inhabitants. Seventeen sub district is an agricultural settlement area which continues to grow, but the standard of living in District Seventeen is still relatively low. The low standard of living in terms 
of aspects of water carrying capacity and carrying capacity of the land. The purpose of this study to determine the value of surplus / deficit by comparing the availability and water requirements, determine the value of the surplus / deficit by comparing the availability and requirement of land, as well as providing recommendations for availability and water demand as well as supply and demand of land, Improving the living standards of the District Seventeen residents were reviewed of water carrying capacity and carrying capacity of the land .

The methodology used to determine the carrying capacity of water and land carrying capacity refers to government regulation of the Environment No. 17 Year 2009 Based on the results of research which refers to government regulation of Environment No. 17 of 2009, to the availability of water in the District Seventeen year * (2014-2023) predicted the same and does not increase the amount of \# 77,451,118 m3 / year due to the land use for the year * (2014 - 2023) is not known, while the water demand in 2013 amounted to 18.4608 million $\mathrm{m} 3$ / year and in the year 2023, an increase in the amount of 23.7753 million $\mathrm{m} 3$ / year. The results obtained from this study is the carrying capacity of water in the District Seventeen surplus this shows the current water availability and predictions for the next 10 years water sufficient in terms of both domestic needs as well as food and other needs. Conditions should now be maintained in accordance with the function of the land. Availability of land in District Seventeen is $8641.489 \mathrm{ha}$, while the need for land is equal to $4807.50 \mathrm{ha}$. For policy development in the agricultural sector as a leading sector in the District Seventeen, it can be geared to meet the needs of a broader market outside the region by developing a marketing accessibility to the outside region. The low standard of living is not related to the District Seventeen with the water carrying capacity and carrying capacity of the land, because the calculation is based on water availability and water demand as well as availability of land and land requirements indicate that the carrying capacity of the environment to meet human needs, both domestic and domestic. Possible causes for the low standard of living caused by other things such as: lack of education, health facilities, and inadequate infrastructure to bring crops residents to the city.

Keywords: District of Seventeen, Environmental Carrying Capacity Deficit, Surplus

\section{Pendahuluan}

daya dukung lingkungan hidup adalah kemampuan lingkungan hidup untuk mendukung perikehidupan manusia, makhluk hidup lain, dan keseimbangan antar keduanya. Padatnya jumlah penduduk berpengaruh terhadap daya dukung lingkungan baik kebutuhan akan sumber daya air dan produktivitas lahan yang tersedia. Pertambahan jumlah penduduk membutuhkan perluasan lahan sebagai wadah aktivitas yang nantinya tumbuh dan berkembang. Apabila perkembangan tersebut tidak dikendalikan dengan baik maka dapat terjadi konversi lahan untuk aktivitas yang tidak sesuai dengan fungsi dan daya dukungnya yang akan berdampak pada penurunan daya dukung lingkungan (Clark, 1992).

Kecamatan Tujuh Belas merupakan daerah pemukiman agraris yang terus berkembang, namun taraf hidup penduduk di Kecamatan Tujuh Belas masih relatif rendah. Taraf hidup rendah adalah dimana keadaan penduduk suatu wilayah pendapatannya sedikit, perumahan yang kurang layak, kesehatan yang buruk, pendidikan yang minim, angka kematian bayi tinggi, harapan hidup rendah dan peluang kerja sedikit. Rendahnya taraf hidup penduduk di Kecamatan Tujuh Belas ditinjau dari aspek daya dukung air dan daya dukung lahannya hal ini berdasarkan dari informasi penduduk yang ada di Kecamatan Tujuh Belas dan kondisi secara umum kehidupan penduduk dan tingkat ekonomi penduduk.

\section{Metodologi}

\section{* Analisis Ketersediaan Air}

Analisis Ketersediaan air dilakukan dengan memperhitungkan ketersediaan air. Persamaan untuk perhitungan ketersediaan air mengacu pada Permen LH No. 17 Tahun 2009 sebagai berikut:

$$
\begin{aligned}
& \mathrm{S}_{\mathrm{A}}=10 \times \mathrm{C} \times \mathrm{R} \times \mathrm{A} . \\
& \mathrm{C}=\frac{\sum(C i \times A i)}{\sum A i} \ldots \ldots \ldots \\
& \mathrm{R}=\sum \frac{R i}{m} \ldots \ldots \ldots \ldots \ldots
\end{aligned}
$$

\section{* Proyeksi Penduduk}

Pada perhitungan proyeksi penduduk yang digunakan untuk mengetahui jumlah kebutuhan air 10 tahun kedepan dapat digunakan dengan 3 metode yaitu: 
a. Metode Aritmatika

Perhitungan proyeksi metode aritmatika dapat dilakukan dengan menggunakan persamaan :

$$
\begin{aligned}
& \mathrm{Pn}=\mathrm{Po}+\mathrm{Ka}(\mathrm{Tn}-\mathrm{To}) \ldots \ldots . . . \\
& \mathrm{Pn}=\mathrm{Po}+\frac{P_{2}-P_{1}}{T_{2}-T_{1}}(\mathrm{Tn}-\mathrm{To}) .
\end{aligned}
$$

b. Metode Geometri

Perhitungan proyeksi metode geometri dapat dilakukan dengan menggunakan persamaan :

$$
\mathrm{Pn}=\mathrm{P}(1+r)^{\mathrm{n}}
$$

c. Metode Least Square

Perhitungan proyeksi metode least square dapat dilakukan dengan menggunakan persamaan :

$$
Y=a+B x
$$

Perhitungan untuk mencari nilai a dan $\mathrm{b}$ dapat menggunakan persamaan sebagai berikut ini :

$$
\begin{aligned}
& a=\frac{\sum Y \cdot \sum X^{2}-\sum X \cdot \sum X Y}{n \cdot \sum X^{2}-\left(\sum X\right)^{2}} . \\
& b=\frac{n \cdot \sum X Y-\sum X \cdot \sum Y}{n \cdot \sum X^{2}-\left(\sum X\right)^{2}} \ldots \ldots \ldots
\end{aligned}
$$

- Analisis Kebutuhan (Demand) Air

Analisis kebutuhan air dengan menggunakan persamaan yang mengacu pada Permen LH No. 17 Tahun 2009:

$D_{A}=N \times K H L_{A}$

\section{* Analisis Ketersediaan Lahan}

Perhitungan ketersediaan lahan dilakukan dengan memperhitungkan ketersediaan lahan. Analisis ketersediaan lahan menggunakan persamaan yang mengacu pada Permen LH No. 17 Tahun 2009 sebagai berikut :

$$
\mathrm{SL}=\frac{\sum(P i X H i)}{H b} \times \frac{1}{P t v b} .
$$

Dalam perhitungan ini, faktor konversi yang digunakan untuk menyetarakan produk non beras adalah harga.

\section{* Analisis Kebutuhan Lahan}

Untuk mengetahui cukup tidaknya persediaan lahan dapat dilakukan dengan cara membandingkan jumlah ketersediaan lahan yang ada dengan kebutuhan lahan. persamaan yang digunakan mengacu pada Permen LH No. 17 Tahun 2009:

$$
D_{L}=N \times K H L
$$

Luas lahan yang dibutuhkan untuk kebutuhan hidup layak per penduduk merupakan kebutuhan hidup layak per penduduk dibagi produktivitas beras lokal.

- Kebutuhan hidup layak per penduduk diasumsikan sebesar 1 ton setara beras/kapita/tahun.

- Daerah yang tidak memiliki data produktivitas beras lokal, dapat menggunakan data rata-rata produktivitas beras nasional sebesar $2400 \mathrm{~kg} / \mathrm{ha} / \mathrm{tahun}$.

\section{* Penentuan Status Daya Dukung Lahan}

Status daya dukung lahan diperoleh dari pembandingan antara ketersediaan lahan $\left(\mathrm{S}_{\mathrm{L}}\right)$ dan kebutuhan lahan $\left(D_{L}\right)$ (Permen LH No. 17 Tahun 2009):

- Bila $S_{L}>D_{L}$, daya dukung lahan dinyatakan surplus.

- Bila $S_{L}<D_{L}$, daya dukung lahan dinyatakan defisit atau terlampaui.

3. Hasil dan Pembahasan

* Analisis Ketersediaan Air

Pehitungan daya dukung air di Kecamatan Tujuh Belas berdasarkan Peraturan Pemerintah Menteri Negara Lingkungan Hidup Nomor 17 Tahun 2009 tentang Pedoman Penentuan Daya Dukung Lingkungan Hidup Dalam Penataan Ruang Wilayah.

\section{A. Perhitungan Koefisien Limpasan Tertimbang}

Penggunaan lahan di lokasi penelitian ada 2 jenis yaitu lahan pertanian dan lahan bukan pertanian. Untuk lahan pertanian terdiri dari lahan sawah dengan kisaran koefisien limpasan (Ci) sekitar 0,30, lahan bukan sawah dengan koefisien limpasan 0,30, dan lahan bukan pertanian dengana koefisien $0,15-0,9$. Perhitungan koefisien limpasan tertimbang disajikan pada tabel 1 : 
Tabel 1 Perhitungan koefisien limpasan tertimbang

\begin{tabular}{|c|c|c|c|c|c|}
\hline No & & Deskripsi Permukaan & $\begin{array}{c}\text { Koefisien } \\
\text { Limpasan } \\
\text { Ci }\end{array}$ & $\begin{array}{l}\text { Luas Lahan } \\
\qquad \begin{array}{c}\mathbf{A i} \\
\text { (Ha) }\end{array}\end{array}$ & (CixAi) \\
\hline \multirow[t]{20}{*}{1.} & \multicolumn{2}{|r|}{ Lahan Pertanian } & & & \\
\hline & A. & Lahan Sawah & & & \\
\hline & & 1. Irigasi Teknis & - & 0 & 0 \\
\hline & & 2. Irigasi Setengah Teknis & 0,3 & 99 & 29,7 \\
\hline & & 3. Irigasi Sederhana & 0,3 & 150 & 45 \\
\hline & & 4. Irigasi Desa/Non PU & - & 0 & 0 \\
\hline & & 5. Tadah Hujan & 0,3 & 171 & 51,3 \\
\hline & & 6. Pasang Surut & - & 0 & 0 \\
\hline & & 7. Lebak & - & 0 & 0 \\
\hline & & 8. Polder dan Sawah Lainnya & - & 0 & 0 \\
\hline & B. & Bukan Lahan Sawah & & & \\
\hline & & 1. Tegal/Kebun & 0,3 & 4.622 & 1386,6 \\
\hline & & 2. Ladang/Huma & 0,3 & 3.116 & 934,8 \\
\hline & & 3. Perkebunan & 0,3 & 5.135 & 1540,5 \\
\hline & & 4. Ditanami Pohon/Hutan Rakyat & 0,3 & 5.757 & 1727,1 \\
\hline & & 5. Tambak & - & 0 & 0 \\
\hline & & 6. Kolam/Tebat/Rumput & 0,3 & 38 & 11,4 \\
\hline & & 7. Padang Pengembalaan/Rumput & - & 0 & 0 \\
\hline & & 8. Sementara tidak diusahakan & 0,3 & 736 & 220,8 \\
\hline & & 9. Lainnya & 0,3 & 262 & 78,6 \\
\hline \multirow[t]{7}{*}{2.} & \multicolumn{2}{|r|}{ Lahan Bukan Pertanian } & & & \\
\hline & & 1. Pekarangan Tidak Ditanami & 0,15 & 732 & 109,8 \\
\hline & & 2. Hutan Negara & 0,18 & 576 & 103,68 \\
\hline & & 3. Rawa - rawa (tidak ditanami) & 0,2 & 151 & 30,2 \\
\hline & & Lainnya & 0,9 & 608 & 547,2 \\
\hline & & \multicolumn{2}{|c|}{ Jumlah $(\Sigma)$} & 22.153 & 6817 \\
\hline & & \multicolumn{3}{|c|}{$\mathrm{C}($ Koefisien Limpasan Tertimbang $)=\frac{\sum\left(C_{i} \times A_{i}\right)}{\sum A_{i}}$} & 0,308 \\
\hline
\end{tabular}

Berdasarkan tabel 1 nilai koefisien tertimbang untuk Kecamatan Tujuh Belas adalah 0,308.

\section{B. Perhitungan Rata - rata Curah Hujan}

Rata - rata aljabar curah hujan tahunan diperoleh berdasarkan perbandingan curah hujan tahunan terhadap jumlah stasiun pengamatan curah hujan, seperti perhitungan berdasarkan persamaan berikut ini :

$$
R=\frac{1136,20}{1}=1136,2 \mathrm{~mm} / \text { tahunan }
$$

maka diperoleh nilai ketersediaan air di Kecamatan Tujuh Belas berdasarkan persamaan sebagai berikut:

$$
\begin{aligned}
& S_{A}=10 \times C \times R \times A \\
& \mathrm{~S}_{\mathrm{A}}=10 \times 0,308 \times 1136,2 \times 22.153=77.451 .118 \mathrm{~m}^{3} / \text { tahun }
\end{aligned}
$$

\section{* Analisis Kebutuhan Air}

\section{A. Perhitungan Aritmatika}

Jumlah penduduk di Kecamatan Tujuh Belas per tahunnya disajikan pada tabel 2 sebagai berikut: 
Tabel 2 Jumlah penduduk Pertahun

\begin{tabular}{|c|c|}
\hline Tahun & $\begin{array}{c}\text { Jumlah } \\
\text { Penduduk } \\
\text { (Jiwa) }\end{array}$ \\
\hline 2008 & 10.196 \\
\hline 2009 & 10.976 \\
\hline 2010 & 10.692 \\
\hline 2011 & 11.206 \\
\hline 2012 & 11.389 \\
\hline 2013 & 11.538 \\
\hline
\end{tabular}

$$
\begin{aligned}
& P_{2023}=11.538+\frac{11.538-10.196}{2013-2008}(2023-2013) \\
& P_{2023}=11.538+264.8(2023-2013) \\
& P_{2023}=14.222 \text { Jiwa }
\end{aligned}
$$

Jadi, dengan menggunakan metode aritmatika jumlah penduduk Kecamatan Tujuh Belas pada tahun 2023 adalah sejumlah $\mathbf{1 4 . 2 2 2}$ jiwa.

\section{B. Perhitungan Geometri}

Perhitungan dengan metode geometri dimulai dengan menghitung persentase pertumbuhan penduduk dari tahun dasar 2008, disajikan pada tabel 3

Tabel 3 Persentase pertumbuhan jumlah penduduk

\begin{tabular}{|c|c|r|r|}
\hline \multirow{2}{*}{ Tahun } & \multirow{2}{*}{$\begin{array}{c}\text { Jumlah } \\
\text { Penduduk } \\
\text { (Jiwa) }\end{array}$} & \multicolumn{2}{|c|}{$\begin{array}{c}\text { Pertumbuhan } \\
\text { Penduduk }\end{array}$} \\
\cline { 3 - 4 } & jiwa & \multicolumn{1}{c|}{$\%$} \\
\hline 2008 & 10.196 & & \\
\hline 2009 & 10.976 & 780 & $7,67 \%$ \\
\hline 2010 & 10.692 & -284 & $-2,59 \%$ \\
\hline 2011 & 11.206 & 514 & $4,81 \%$ \\
\hline 2012 & 11.389 & 183 & $1,63 \%$ \\
\hline 2013 & 11.538 & 149 & $1,31 \%$ \\
\hline
\end{tabular}

Perhitungan persentase pertumbuhan penduduk rata - rata (rasio) adalah sebagai berikut :

$$
\begin{aligned}
& R=\frac{12,83 \%}{2013-2008} \\
& R=0,0256 \approx 2,56 \%
\end{aligned}
$$

Perhitungan jumlah penduduk Kecamatan Tujuh Belas pada tahun 2023 dapat dihitung dengan menggunakan persamaan sebagai berikut:

$$
\begin{aligned}
\mathrm{Pn} & =\mathrm{Po}(1+r)^{n} \\
\mathrm{P}_{2023} & =11.538(1+2,56 \%)^{10} \\
\mathrm{P}_{2023} & =14.860 \text { Jiwa }
\end{aligned}
$$

Jadi, dengan menggunakan metode geometri pertumbuhan penduduk Kecamatan Tujuh Belas pada tahun 2023 adalah sejumlah 14.860 jiwa.

\section{Perhitungan Least Square}

Perhitungan proyeksi untuk metode Least Square disajikan pada tabel 4 dibawah ini: 
Tabel 4 Perhitungan Proyeksi untuk Metode Least Square

\begin{tabular}{|c|c|c|r|r|}
\hline 'Tahun & $\mathbf{X}$ & \multicolumn{1}{|c|}{$\mathbf{Y}$} & \multicolumn{1}{c|}{ X.Y } & \multicolumn{1}{|c|}{$\mathbf{X}^{\mathbf{2}}$} \\
\hline 2008 & 1 & 10.196 & 10.196 & 1 \\
\hline 2009 & 2 & 10.976 & 21.952 & 4 \\
\hline 2010 & 3 & 10.692 & 32.076 & 9 \\
\hline 2011 & 4 & 11.206 & 44.824 & 16 \\
\hline 2012 & 5 & 11.389 & 56.945 & 25 \\
\hline 2013 & 6 & 11.538 & 69.228 & 36 \\
\hline$\Sigma$ & 21 & 65.997 & 235.221 & 91 \\
\hline
\end{tabular}

Maka nilai a dan $\mathrm{b}$ adalah sebagai berikut :

$$
\begin{aligned}
a & =\frac{(65.997 \times 91)-(21 \times 235.221)}{(6 \times 91)-(21)^{2}} \\
& =10153,2 \\
b & =\frac{(6 \times 235.221)-(21 \times 65.997)}{(6 \times 91)-(21)^{2}} \\
& =241,8
\end{aligned}
$$

Sehingga, dengan menggunakan persamaan least square dapat dihitung proyeksi pertumbuhan penduduk Kecamatan Tujuh Belas pada tahun 2023, persamaannya adalah sebagai berikut:

$$
\begin{aligned}
Y & =a+B x \\
Y & =10153,2+(241,8(x) \\
& =10153,2+(241,8 \times(2023-2013) \\
& =12.571 \text { Jiwa }
\end{aligned}
$$

Jadi, dengan menggunakan metode Least square pertumbuhan penduduk Kecamatan Tujuh Belas pada tahun 2023 adalah sejumlah 12.571 jiwa.

Dari hasil perhitungan ketiga metode tersebut dapat kita simpulkan bahwa metode yang digunakan untuk menghitung kebutuhan penduduk 10 tahun kedepan (2013 - 2023) adalah dengan menggunakan metode geometri, dikarenakan dengan metode geometri menghasilkan jumlah penduduk yang terbesar/tertinggi yaitu sebanyak 14.860 jiwa. Jika yang digunakan jumlah penduduk yang tinggi maka akan menghasilkan kebutuhan yang tinggi.

kebutuhan air untuk hidup layak diperoleh dari kebutuhan air untuk keperluan domestik dan untuk kebutuhan air berdasarkan Permen LH No.17 Tahun 2009 sebesar 1600 mªir/kapita/tahun. Sehingga kebutuhan air di Kecamatan Tujuh Belas berdasarkan persamaan berikut ini:

$$
\begin{aligned}
& \mathrm{D}_{\mathrm{A}}=\mathrm{N} \times \mathrm{KHL}_{\mathrm{A}} \\
& D_{A}=11.538 \text { jiwa } \times 1600 \mathrm{~m}^{3} \text { air } / \text { kapita/tahun }=18.460 .800 \mathrm{~m}^{3} / \text { tahun }
\end{aligned}
$$

$\mathrm{m}^{3} /$ tahun.

Jadi, kebutuhan air pada Kecamatan Tujuh Belas pada tahun 2013 adalah sebesar $\mathbf{1 8 . 4 6 0 . 8 0 0}$

\section{* Penentuan Status Daya Dukung Air}

Penentuan status daya dukung air di Kecamatan Tujuh Belas disajikan pada tabel 5 sebagai berikut: 
Tabel 5 Status Daya Dukung Air Kecamatan Tujuh Belas

\begin{tabular}{|c|l|l|l|l|}
\hline No & Tahun & $\begin{array}{c}\text { SA } \\
\text { (m3/tahun ) }\end{array}$ & $\begin{array}{c}\text { DA } \\
\text { (m3/tahun ) }\end{array}$ & Status Daya Dukung Air \\
\hline 1 & 2013 & 77.451 .118 & 18.460 .800 & surplus \\
\hline 2 & $2014^{*}$ & $77.451 .118 \#$ & 18.933 .812 & surplus \\
\hline 3 & $2015^{*}$ & $77.451 .118 \#$ & 19.418 .944 & surplus \\
\hline 4 & $2016^{*}$ & $77.451 .118 \#$ & 19.916 .507 & surplus \\
\hline 5 & $2017^{*}$ & $77.451 .118 \#$ & 20.426 .818 & surplus \\
\hline 6 & $2018^{*}$ & $77.451 .118 \#$ & 20.950 .204 & surplus \\
\hline 7 & $2019^{*}$ & $77.451 .118 \#$ & 21.487 .002 & surplus \\
\hline 8 & $2020^{*}$ & $77.451 .118 \#$ & 22.037 .553 & surplus \\
\hline 9 & $2021^{*}$ & $77.451 .118 \#$ & 22.602 .210 & surplus \\
\hline 10 & $2022^{*}$ & $77.451 .118 \#$ & 23.181 .336 & surplus \\
\hline 11 & $2023^{*}$ & $77.451 .118 \#$ & 23.775 .300 & serta \\
\hline
\end{tabular}

Penentuan status daya dukung lingkungan terhadap pengelolaan serta penggunaan sumberdaya air dilakukan dengan membandingkan total ketersediaan air dan total kebutuhan air. Dari hasil perhitungan daya dukung dengan menggunakan konsep perhitungan sesuai Peraturan Menteri Lingkungan Hidup No. 17 Tahun 2009, kebutuhan air pada Kecamatan Tujuh Belas pada tahun 2013 adalah sebesar $18.460 .800 \mathrm{~m}^{3} /$ tahun. Berdasarkan perhitungan proyeksi selama 10 tahun kedepan *(2014 - 2023) merupakan prediksi yang diketahui kebutuhan airnya terus meningkat. Jika diperkirakan ketersediaan air (SA) tetap dan tidak bertambah yaitu sebesar \#77.451.118 $\mathrm{m}^{3} /$ tahun dikarenakan dalam penggunaan lahan untuk tahun kedepannya (2014 2023) tidak diketahui, jadi ketersediaan air pada tahun 2013 dijadikan acuan untuk memprediksi tahun (2014 - 2023). Apabila ketersediaan air diasumsikan akan tetap dan tidak bertambah maka dapat dilihat status daya dukung air surplus (mencukupi kebutuhan air) baik dari segi kebutuhan domestik maupun kebutuhan pangan dan lainnya.

Oleh karena itu, untuk menjamin ketersediaan air pada Kecamatan Tujuh Belas tetap mencukupi untuk kebutuhan hidup layak penduduk maka masyarakat setempat agar mampu mempertahankan fungsi lahan menurut aspek konservasi dan mencegah degradasi maka langkah yang dilakukan oleh manajemen pertanian dan perkebunan adalah dengan mempertahankan wilayah konservasi sebagai penampung alami. Hal ini sesuai dengan penelitian Rusmayadi (2011) bahwa dengan tetap mempertahankan wilayah konservasi sebagai penampungan alami.Guna memenuhi kebutuhan air, fungsi lingkungan yang terkait dengan sistem tata air harus dilestarikan dengan tetap mempertimbangkan kelestarian lingkungan sekitar. Oleh karena itu, potensi sumber daya air yang tersedia perlu direncanakan dengan baik pemanfaatan dan konservasinya. Selain itu, apabila permasalahan ketersediaan air tidak disikapi dengan pemanfaatan air yang lebih proporsional, maka dikhawatirkan akan terjadinya krisis air kedepannya.

\section{* Analisis Ketersediaan Lahan}

Perhitungan ketersediaan lahan dilakukan berdasarkan Permen LH No. 17 Tahun 2009 tentang Pedoman Penentuan Daya Dukung Lingkungan Hidup dalam Penataan Ruang Wilayah. Berdasarkan hal tersebut, data yang diperlukan dalam perhitungan ketersediaan lahan yaitu produksi aktual tiap jenis komoditi $(\mathrm{Pi})$ dan harga beras di tingkat produsen $(\mathrm{Hb})$, harga satuan tiap komoditi ditingkat produsen $(\mathrm{Hi})$, dan produktivitas beras di Kecamatan Tujuh Belas $\left(\mathrm{Pt} v_{b}\right)$. Perhitungan total nilai produksi tiap komoditas di Kecamatan Tujuh Belas disajikan pada tabel 6 sebagai berikut:

Tabel 6 Hasil Perhitungan nilai produksi total Kecamatan Tujuh Belas

\begin{tabular}{|c|c|c|c|c|}
\hline No & Jenis Komoditas & $\begin{array}{l}\text { Produksi Aktual } \\
\text { (Pi) } \\
\text { (Kg) }\end{array}$ & $\begin{array}{c}\text { Harga Satuan } \\
\text { Komoditas } \\
\text { Hi } \\
\text { (Rp/Kg) }\end{array}$ & $\begin{array}{l}\text { Nilai Produksi PixHi } \\
\text { (Rp) }\end{array}$ \\
\hline 1. & Jagung & 39.306 .000 & 3.000 & 117.918 .000 .000 \\
\hline 2. & Ubi Kayu & 2.890 .000 & 1.500 & 4.335 .000 .000 \\
\hline 3. & Ubi Jalar & 65.770 & 3.000 & 197.310 .000 \\
\hline
\end{tabular}




\begin{tabular}{|c|c|c|c|c|}
\hline 4. & Kacang Tanah & 5.390 & 10.000 & 53.900 .000 \\
\hline 5. & Kacang Kedelai & 35.310 & 8.000 & 282.480 .000 \\
\hline 6. & Padi & 2.780 .000 & 5.000 & 13.900 .000 .000 \\
\hline 7. & Karet & 732.000 & 11.000 & 8.052 .000 .000 \\
\hline 8. & Kelapa Sawit & 626.000 & 1.500 & 939.000 .000 \\
\hline 9. & Lada & 154.000 & 25.000 & 3.850 .000 .000 \\
\hline 10. & Kemiri & 10.000 & 4.500 & 45.000 .000 \\
\hline 11. & Kakao & 10.000 & 8.000 & 80.000 .000 \\
\hline \multirow[t]{9}{*}{12.} & \multicolumn{4}{|l|}{ Sayuran } \\
\hline & a. Sawi & 112.000 & 3.000 & 336.000 .000 \\
\hline & b. Kacang panjang & 668.000 & 3.500 & 2.338 .000 .000 \\
\hline & c. Cabe Besar & 391.000 & 3.000 & 1.173 .000 .000 \\
\hline & d. Cabe Rawit & 72.000 & 40.000 & 2.880 .000 .000 \\
\hline & e. Tomat & 438.000 & 9.000 & 3.942 .000 .000 \\
\hline & f. Terong & 560.000 & 3.000 & 1.680 .000 .000 \\
\hline & g. Buncis & 582.000 & 6.000 & 3.492 .000 .000 \\
\hline & h. Ketimun & 57.000 & 2.500 & 142.500 .000 \\
\hline \multirow[t]{7}{*}{13.} & \multicolumn{4}{|l|}{ Buah-buahan } \\
\hline & a. Nangka & 10.700 & 5.000 & 53.500 .000 \\
\hline & b. Cempedak & 10.700 & 1.000 & 10.700 .000 \\
\hline & c. Durian & 2.000 & 5.000 & 10.000 .000 \\
\hline & d. Pisang & 20.000 & 10.000 & 200.000 .000 \\
\hline & e. Petai & 500 & 10.000 & 5.000 .000 \\
\hline & f. Sukun & 1.200 & 1.000 & 1.200 .000 \\
\hline \multicolumn{4}{|c|}{ TOTAL } & 165.916 .590 .000 \\
\hline
\end{tabular}

Perhitungan ketersediaan lahan $\left(\mathrm{S}_{\mathrm{L}}\right)$ berdasarkan persamaan sebagai berikut:

$$
S L=\frac{165.916 .590 .000}{8.000} \times \frac{1}{2.400}=8641,489 \mathrm{Ha}
$$

Jadi, ketersediaan lahan (SA) di Kecamatan Tujuh Belas adalah 8641,489 Ha.

* Analisis Kebutuhan Lahan

Kebutuhan lahan adalah kebutuhan hidup minimum. Tekanan penduduk terhadap daya dukung lahan dapat ditentukan berdasarkan nilai perbandingan antara jumlah penduduk dan persentase petani dengan luas lahan minimal untuk hidup layak (Soermarwoto, 2000).

\section{* Kebutuhan Lahan Untuk Hidup Layak}

Luas lahan yang dibutuhkan untuk kebutuhan hidup layak per penduduk merupakan kebutuhan hidup layak per penduduk dibagi produktivitas beras lokal. Menurut Pemen LH No. 17 Tahun 2009, untuk kebutuhan hidup layak per penduduk diasumsikan sebesar 1 ton setara beras/kapita/tahun. Seperti yang telah diketahui di atas, produktivitas beras di Kecamatan Tujuh Belas adalah 2.400 $\mathrm{kg} / \mathrm{ha} / \mathrm{tahun}$. Perhitungan kebutuhan lahan untuk hidup layak adalah sebagai berikut:

$$
\begin{aligned}
\mathrm{KHL}_{\mathrm{L}} & =\frac{\text { Kebutuhan hidup layak per penduduk }}{\text { produktivitas beras lokal }} \\
\mathrm{KHL}_{\mathrm{L}} & =\frac{1 \text { ton } \text { beras } / \text { kapita } / \text { tahun }}{2.400 \mathrm{~kg} / \mathrm{ha} / \mathrm{tahun}} \\
\mathrm{KHL}_{\mathrm{L}} & =0,417 \mathrm{ha} / \text { orang }
\end{aligned}
$$

Jadi, kebutuhan lahan untuk hidup layak di Kecamatan Tujuh Belas adalah 0,417 ha/ orang.

\section{* Analisis Kebutuhan Lahan}

Kebutuhan lahan diperoleh dengan cara mengalikan jumlah penduduk $(\mathrm{N})$ dengan kebutuhan lahan untuk hidup layak (KHL $)$. Jumlah penduduk berdasarkan data Badan Pusat Statistik Kabupaten Bengkayang Kecamatan Tujuh Belas adalah 11.538 jiwa, sedangkan kebutuhan lahan untuk hidup 
layak $\left(\mathrm{KHL}_{\mathrm{L}}\right)$ berdasarkan hasil perhitungan di atas adalah 0,417 ha/orang. Perhitungan kebutuhan lahan $\left(D_{L}\right)$ dengan menggunakan persamaan sebagai berikut :

$\mathrm{D}_{\mathrm{L}} \quad=\mathrm{N} \times \mathrm{KHL} \mathrm{L}$

$\mathrm{D}_{\mathrm{L}} \quad=11.538 \times 0,417=4807,50 \mathrm{Ha}$

Jadi, Kebutuhan lahan untuk Kecamatan Tujuh Belas adalah sebesar 4807,50 Ha

Berdasarkan hasil perhitungan yang diperoleh di atas dapat disimpulkan nilai ketersediaan dan kebutuhan lahan sebagai berikut:

- ketersediaan lahan $\left(\mathrm{S}_{\mathrm{L}}\right)$ adalah 8641,489 ha

- kebutuhan lahan $\left(D_{L}\right)$ adalah 4807,50 ha.

Dengan demikian, maka diperoleh nilai $S_{L}<D_{L}$ dan daya dukung lahan dinyatakan surplus atau mencukupi. Dari hasil perhitungan daya dukung dengan menggunakan konsep perhitungan sesuai Peraturan Menteri Lingkungan Hidup No. 17 Tahun 2009, Kecamatan Tujuh Belas mempunyai status daya dukung lahan yang mencukupi kebutuhan akan produksi hayati terhadap penduduk yang tinggal di Kecamatan Tujuh Belas. Dapat dikatakan bahwa ketersediaan akan lahan di Kecamatan Tujuh Belas lebih besar dari kebutuhan lahan di Kecamatan Tujuh Belas. Agar daya dukung lahan tetap dalam keadaan surplus penduduk Kecamatan Tujuh Belas mempertahankan kondisi yang sekarang dan reboisasi pada tanah yang gundul. Daya dukung lahan dinyatakan surplus dalam memenuhi kebutuhan produk hayati, dipengaruhi oleh beberapa faktor yaitu (As-syakur, 2011):

a. Tingkat keragaman komoditas pada sektor pertanian yang besar

b. Sebagian besar masyarakat bekerja pada di sektor pertanian

c. Sektor pertanian merupakan sektor yang memiliki keunggulan komparatif dan kompetitif

d. Alih fungsi lahan pertanian menjadi lahan bukan pertanian relatif kecil

e. Memiliki jenis tanah yang subur dan iklim yang sesuai untuk pertanian

Kebijakan perlindungan lahan pertanian produktif diarahkan untuk menekan alih fungsi lahan dengan menerapkan kebijakan insentif dan disinsentif, mekanisme perijinan, dan penyuluhan.

Jadi, rendahnya taraf hidup penduduk Kecamatan Tujuh Belas tidak berkaitan dengan daya dukung air dan daya dukung lahan, karena berdasarkan perhitungan ketersediaan air dan kebutuhan air serta ketersediaan lahan dan kebutuhan lahan menunjukkan bahwa daya dukung lingkungannya mencukupi untuk kebutuhan manusia baik domestik maupun domestik. Kemungkinan yang menyebabkan taraf hidup rendah dapat disebabkan oleh hal lain seperti infrastuktur yang tidak memadai ( jalan, sarana kesehatan dan sarana pendidikan), pendapatan penduduk yang masih tergolong rendah, perumahan yang kurang layak, dan peluang kerja yang kurang (Septiana, 2012).

\section{Kesimpulan}

Berdasarkan hasil analisis, ketersediaan air di Kecamatan Tujuh Belas pada tahun 2013 adalah sebesar $77.451 .118 \mathrm{~m}^{3} /$ tahun, sedangkan kebutuhan air pada tahun 2013 sebesar 18.460 .800 $\mathrm{m}^{3} /$ tahun dan pada tahun 2023 kebutuhan airnya meningkat sebesar $23.775 .300 \mathrm{~m}^{3} /$ tahun, sedangkan untuk ketersediaan airnya tetap dan tidak bertambah. Jadi, Daya dukung air di Kecamatan Tujuh Belas dinyatakan surplus, karena ketersediaan airnya lebih besar dari kebutuhan airnya. Ketersediaan lahan di Kecamatan Tujuh Belas adalah sebesar 8641,489 ha, sedangkan untuk kebutuhan lahannya adalah sebesar 4807,50 ha. Jadi daya dukung lahan yang ada di Kecamatan Tujuh belas dinyatakan surplus karena ketersediaan lahannya lebih besar dari kebutuhan lahannya. Dari hasil perhitungan ketersediaan dan kebutuhan air serta ketersediaan dan kebutuhan lahan dapat diajukan rekomendasi atau kebijakan untuk Kecamatan Tujuh Belas, untuk mempertahankan ketersediaan air pada Kecamatan Tujuh Belas agar tetap mencukupi kedepannnya dan untuk memenuhi kebutuhan masyarakat setempat maka masyarakat harus mampu mempertahankan fungsi lahan menurut aspek konservasi untuk mencegah degradasi, sedangkan untuk kebijakan pengembangan di sektor pertanian sebagai sektor unggulan di Kecamatan Tujuh Belas, maka dapat diarahkan untuk memenuhi kebutuhan pasar yang lebih luas ke luar wilayah dengan mengembangkan aksesibilitas pemasaran ke luar wilayah. Dalam hal ini, kontrak kerjasama kerjasama dengan industri pengolahan pangan di luar daerah perlu difasilitasi oleh Pemerintah Daerah setempat. Rendahnya taraf hidup penduduk Kecamatan Tujuh Belas tidak berkaitan dengan 
daya dukung air dan daya dukung lahan, karena berdasarkan perhitungan ketersediaan air dan kebutuhan air serta ketersediaan lahan dan kebutuhan lahan menunjukkan bahwa daya dukung lingkungannya mencukupi untuk kebutuhan manusia baik domestik maupun domestik. Kemungkinan yang menyebabkan taraf hidup rendah di Kecamatan Tujuh disebabkan oleh hal lain seperti : infrastuktur yang tidak memadai ( jalan, sarana kesehatan dan sarana pendidikan), pendapatan penduduk yang masih tergolong rendah, perumahan yang kurang layak, dan peluang kerja yang kurang.

\section{DAFTAR PUSTAKA}

As-syakur, A. R. 2011. Perubahan Penggunaan Lahan di Provinsi Bali. Jurnal Ecotrophic Vol. 6 No. 1. 1-7

Badan Pusat Statistik Kabupaten Bengkayang. 2013. Kecamatan Tujuh Belas Dalam Angka Tahun 2013. BPS Bengkayang.

Clark, J. R. 1992. Intragated Management Of Coastal Zones. FAO Fisheries Technical Paper No. 327. United Nations/FAO, Rome. 167 PP.

Permen LH No.17. 2009. Pedoman Penentuan Daya Dukung Lingkungan Hidup Dalam Penataan Ruang Wilayah

Rusmayadi, G. 2011. Dinamika Kandungan Air Tanah Di Areal Perkebunan Kelapa Sawit Dan Karet Dengan Pendekatan Neraca Air Tanaman. Fakultas Pertanian UNLAM. Vol. 18. HIm 86-92.

Soemarwoto, O. 2000. Analisis Dampak Lingkungan. Yogyakarta : Gadjah Mada University Press.

Septiana, R. 2012. Efektifitas Model Pembelajaran Inkuiri Terbimbing Pada Materi Hidrolisis Garam dalam Meningkatkan Keterampilan Memberikan Penjelasan Sederhana dan Menerapkan Konsep yang Dapat Diterima. Jurnal Pendidikan Kimia UNILA. Volume 1 nomor 2. 